\title{
PETROGRAFIA DAS ROCHAS DO COMPLEXO METACARBONATÍTICO DE ANGICO DOS DIAS, DIVISA BAHIA/PIAUÍ, BRASIL.
}

\author{
PETROGRAPHY OF THE ROCKS OF THE METACARBONATITE COMPLEX OF ANGICO DOS \\ DIAS, BAHIA / PIAUÍ LANDMARK, BRAZIL.
}

\author{
Rejane Lima LUCIANO ${ }^{1}$, Antonio Misson GODOY ${ }^{2}$ \\ ${ }^{1}$ Programa de Pós-Graduação em Geociências, Instituto de Geociências e Ciências Exatas \\ Companhia Baiana de Pesquisa Mineral - CBPM, Salvador. Email: rejane.lima@cbpm.ba.gov.br \\ ${ }^{2}$ Universidade Estadual Paulista - UNESP Departamento de Petrologia e Metalogenia, Instituto de Geociências e Ciências Exatas. \\ Rio Claro, SP. Email: mgodoy@rc.unesp.br
}

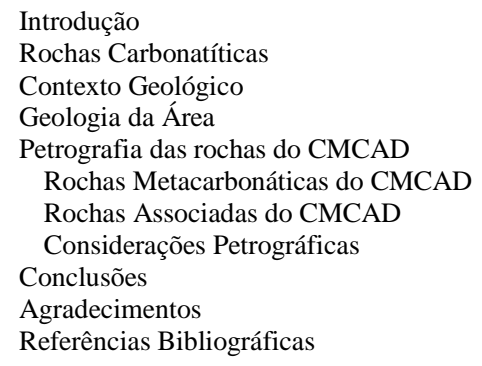

RESUMO - As rochas do Complexo Metacarbonatítico de Angico dos Dias são lavradas para minerais fosfatados pela Unidade de Mineração GALVANI, na região do extremo noroeste do Estado da Bahia. São rochas de idade paleoproterozoica que ocorrem intrusivas em rochas arqueana-paleoproterozoica do Complexo Gnáissico-Migmatítico Sobradinho-Remanso e, são constituídas por metacarbonatitos primários, metassienitos variados, metapiroxenitos, metassienogranitos, tremolitito, biotita xisto, metalamprófiros e fenitos. Os depósitos secundários e/ou residuais formam-se por processos supergênicos, que geraram um manto de intemperismo instalado sobre o carbonatito que deu origem ao depósito de fosfato residual, denominado de apatitito. Estes depósitos encontram-se associados com as carapaças descontínuas ferruginosas e/ou silicificadas. As rochas carbonatíticas são classificadas principalmente como calciocarbonatito e/ou sovito e são constituídas dominantemente por calcita e apatita e, subordinado dolomita, olivina, flogopita e magnetita. São originados por cristalização fracionada, por segregação gravítica, principal mecanismo responsável pela evolução do magma, originando um acamamento cumulático, que é definido por níveis diferenciados, mais enriquecidos em apatita, minerais ferro-magnesiano e magnetita. O processo de diferenciação permite a geração de variados litotipos de rochas ultrabásicas e possibilitam individualizar principalmente cinco tipos petrográficos de carbonatitos na lavra: o apatita metacarbonatito; olivinaapatita metacarbonatito; flogopita-apatita-olivina metacarbonatito; olivina-apatita biotita/flogopita metacarbonatito e metacarbonatito silicificado. As associações minerais identificam metamorfismo em fácies anfibolito alto, apresentando paragêneses superimpostas retrometamórficas em xisto verde médio a alto.

Palavras-chave: carbonatito; mineralogia; petrografia.

\begin{abstract}
The Angico dos Dias Metacarbonatite Complex rocks are mined for mineral phosphate by GALVANI Mining Unit, in the extreme northwest region of Bahia State. These are intrusive Paleoproterozoic rocks occurring in Archean-Paleoproterozoic rocks of the Sobradinho-Remanso gneissic-migmatitic Complex and consist of primary metacarbonatites, varied metasyenites, metapyroxenites, metassyenogranites, tremolitite, biotite schist, metalamprophyres and fenites. Secondary and/or residual deposits are formed by supergene processes, generating weathering mantle installed on the carbonatite which gave rise to residual phosphate deposit, called apatite-rock. These deposits are associated with ferruginous and/or silicified discontinuous shell. The carbonatite rocks are mainly classified as calcium-carbonatite and/or sovite and consist dominantly by calcite and apatite and subordinate dolomite, olivine, phlogopite and magnetite. These arise by fractional crystallization, gravitational segregation, main mechanism responsible for magma evolution, generating a cumulatic layering, which is defined by different levels, more enriched in apatite, iron-magnesium minerals and magnetite. The process of differentiation allowed the generation of various lithologies of ultrabasic rocks and enables to individualize mainly five petrographic types of carbonatites in the mining: the apatite metacarbonatite; olivineapatite metacarbonatite; phlogopite-apatite-olivine metacarbonatite; olivine-apatite biotite/phlogopite metacarbonatite and silicified metacarbonatite. The mineral assemblages identify high amphibolite facies metamorphism, with superimposed parageneses by retrograde metamorphism over medium to high green schist.
\end{abstract}

Keywords: carbonatite; mineralogy; petrography.

\section{INTRODUÇÃO}

Os estudos das rochas carbonatíticas iniciaram-se no fim do século XIX, e tiveram como premissa, o reconhecimento quanto aos aspectos mineralógico e petrológico deste conjunto de rochas. A primeira descrição deste conjunto de rochas deve-se a Bose (1884), que reconheceu os carbonatitos, como produto magmático, associados a complexos alcalinos na região da Índia e, em seguida Högbom (1895) reconhece a rochas carbonatíticas em complexos alcalinos da Suécia. A partir de descrições mineralógicas, foi definida a primeira proposta de origem do magma carbonatítico, como resultado do produto final da diferenciação de magmas alcalinos (Stutzer, 1907). 
O termo carbonatito somente foi usado e definido por Brögger (1921) para descrição de rochas carbonatíticas e/ou carbonatito na Noruega e, foi definida como uma "rocha ígnea composta predominantemente por carbonato e que ocorre associado a um maciço sílicocarbonático”. A definição mais aceita descreve o carbonatito como um tipo especial de rocha rica em carbonatos, geneticamente relacionada ao processo de formação de magmas alcalinos (Pecora, 1956).

Ainda, esta definição pode ser estendida aos depósitos ricos em carbonatos formados por fluidos magmáticos quentes, eliminando a conotação genética de magma, sugerida por Brögger (1921), exclusiva de maciço ígneo de composição sílico-carbonático. Heinrich (1966) simplificou a definição com "carbonatito é uma rocha rica em carbonato de derivação magmática aparente ou similar”.

Segundo a classificação e nomenclatura proposta pela IUGS (International Union Geological Sciences), publicada por Streckeisen (1979), definiu-se "carbonatito como rocha ígnea que contém mais de $50 \%$ de minerais magmáticos carbonáticos primários”. Geralmente os carbonatitos compreendem associações de carbonatos: dolomita, calcita, calcita-dolomita, ankerita e siderita, além de grande variedade de minerais acessórios. Todas as recomendações para a classificação de carbonatitos proposta pela subcomissão da IUGS são referidas por (Woolley \& Kempe, 1989).

As rochas carbonatíticas constituem pequena ocorrência e são um tipo de magma relativamente raro e com uma mineralógica muito específica, o que dificultou o avanço do seu conhecimento, mas o interesse mineralógico-petrológico e os raros aspectos econômicos destes complexos alcalinocarbonatíticos, contribuíram para descoberta de novos corpos e o avanço do conhecimento.

A maioria dos estudos existentes dos depósitos carbonatíticos, se concentram na valorização econômica dos bens minerais, necessitam, portanto, de um bom suporte de informações geológica e mineralógica no sentido de um bom resultado no conhecimento das suas diversidades mineralógicas.

Atualmente, raras ocorrências de rochas carbonatíticas no Brasil estão em fase de exploração principalmente para fosfato e nióbio, além dos trabalhos iniciais com a vertente direcionada aos estudos de elementos de terras raras. Comin-Chiaramonti \& Gomes (2005) apontam as principais ocorrências das rochas carbonatíticas que se encontram em fase de exploração e, respondem pela maior parte da produção Araxá, Catalão I e II, Jacupiranga, Tapira e Juquiá, além de Angico dos Dias, o único complexo carbonatítico brasileiro Paleoproterozoico identificado, apresentando idade de 2.011 $\pm 6 \mathrm{Ma}$ (Mariano, 1987). Secundariamente, adiciona-se a estas as ocorrências de rochas carbonatíticas de Anitápolis, Iperó, Patrocínio e Ouvidor.

Dos carbonatitos se obtém uma série de produtos, como fósforo a partir de apatita, ferro a partir de magnetita, nióbio a partir de pirocloro, zircônio a partir de badeleíta e, diversos elementos terras raras a partir de monazita e bastnasita, entre outros minerais.

Em alguns maciços carbonatíticos a rocha parental possui um elevado teor natural de apatita tornando-a explorável, sendo denominado de minério de fosfato primário. Porém, em países de clima tropical é comum que no manto de alteração ocorra a concentração de apatita, constituindo o minério principal. Os depósitos mais frequentes de fosfatos encontram-se associados aos complexos alcalinos-carbonáticos, que apresentam uma complexidade mineralógica acentuada e em razão de variações intensas das suas rochas resultam na consequente qualidade e complexidade de exploração do minério secundário.

À superimposição de processos de alteração intempérica e laterização na formação dos depósitos de fosfato, faz com que cada depósito apresente peculiaridades no que se refere aos minerais de fosfato presentes, sendo a apatita o principal mineral possível de aproveitamento (Kahn et al., 1990).

O Brasil é um dos maiores produtores mundiais de alimentos, sendo o agronegócio um dos mais fortes segmentos da sua economia. No entanto, a maioria dos seus solos são pobres nos macronutrientes e a produção de fertilizantes não acompanhou o desenvolvimento da agropecuária. Como quinto produtor mundial de alimentos e agronegócio e 
consequentemente, o país tornou-se o terceiro maior importador mundial de macronutrientes e o segundo no caso específico dos fosfatados.

Neste contexto, o conjunto de rochas do Complexo Metacarbonatito de Angico dos Dias (CMCAD) reflete a sua importância no cenário de fosfato nacional, constituindo a única lavra e fonte de fosfato da região.
Luciano (2016) e Luciano \& Godoy (2017) apresentam novos dados geológicos, petrográficos e geoquímicos de grande importância na lavra.

Neste trabalho pretende-se a divulgação de novos dados geológicos-mineralógicos, permitindo assim, um melhor conhecimento da sua variedade mineralógica e da sua potencialidade econômica.

\section{ROCHAS CARBONATÍTICAS}

Woolley \& Kempe (1989) enumeram cerca de 450 ocorrências de carbonatitos conhecidos em todo mundo, sendo que $40 \%$ deste estão localizadas no continente africano. Deste total, segundo Woolley (2001), cerca de 330 são carbonatitos que se encontram associados a complexos alcalino-carbonatitos e, somente cerca de 120 são corpos de carbonatito isolados. As fácies intrusivas dominam claramente sobre as extrusivas, representando estas últimas apenas aproximadamente $\quad 10 \%$ das ocorrências conhecidas em todo o mundo.

A partir de dados mais atualizados de Woolley \& Kjarsgaard (2008), reportam a ocorrência de 527 carbonatitos no mundo, sendo 29 corpos descritos no Brasil. Dessas ocorrências mundiais, cerca de $76 \%$ estão temporalmente e espacialmente associadas com rochas silicáticas alcalinas-carbonáticas. Segundo, Brod (2014) os depósitos, prospectos e ocorrências mundiais contemplam 744 ocorrências.

Os carbonatitos são identificados desde o Proterozoico ao Recente e encontram-se dominantemente associados a um ambiente de intraplaca continental anorogênicos, a partir de hot spots em rifts, separação continental e extensões continentais de falhas transformantes. Secundariamente, ocorrem associados com eventos orogênicos, em margens continentais e separação de placas e ilhas oceânicas. Estão registradas somente duas ocorrências em ambientes intraplaca oceânico, as ilhas Cabo Verde e Canárias e o único vulcão ativo de lavas com composição carbonatítica no mundo ativo é o Ol Doinyio Lengai, na Tanzânia.

Os carbonatitos segundo Streckeisen (1979) são uma rocha magmática intrusiva ou extrusiva e com mais de $50 \%$ de minerais carbonatados e apresentando a sílica inferior a 10\%. Para a nomenclatura destas rochas deve-se ter em conta o carbonato dominante presente, que deverá adjetivar o nome da rocha, por exemplo carbonatito calcítico, ou o mineral carbonático deverá preceder o nome da rocha, por exemplo calcita carbonatito. Os carbonatitos podem ainda conter um prefixo ao nome, quando à fase mineral acessória dominante for menor que 5\%, por exemplo carbonatito calcítico com pirocloro, ou pode preceder o nome da rocha, quando a fase mineral principal for maior que $5 \%$, por exemplo olivina carbonatito.

Pode-se utilizar para a fase mineral de importância, mais de um mineral, sendo que o primeiro mineral que acompanha o termo carbonatito é o de maior porcentagem, por exemplo piroxênio-olivina carbonatito. Quando a necessidade de realçar características, a exemplo da granulação da rocha, deve-se usar calcita carbonatito de granulação grossa ou simplificar, por exemplo calcita carbonatito grosso.

Esta nomenclatura atual é a recomendada, mas alguns termos da literatura antiga ainda são utilizáveis: quando domina cálcio o mineral é calcita $\mathrm{CaCO}_{3}$, a rocha é designada de carbonatito calcítico ou sovito (granulação grossa) e alvikito (granulação fina), quando domina (cálcio e magnésio) o mineral é dolomita $\mathrm{CaMg}\left(\mathrm{CO}_{3}\right)_{2}$, a rocha é designada de carbonatito dolomítico ou rauhaugito (granulação grossa) e beforsito (granulação fina), quando domina (cálcio, magnésio e ferro) o mineral é siderita $\left(\mathrm{FeCO}_{3}\right)$ e/ou ankerita [Ca(Mg,Fe $\left.)\left(\mathrm{CO}_{3}\right)_{2}\right]$, a rocha é designada de carbonatito siderítico ou ankerítico, e quando domina o (sódio e o potássio), os minerais são nyerereita $\left[\mathrm{Na} 2 \mathrm{Ca}\left(\mathrm{Co}_{3}\right)_{2}\right]$ e gregoryita $\left[\left(\mathrm{Na}_{2}\right.\right.$, $\left.\mathrm{K}_{2}, \mathrm{Ca}\right) \mathrm{CO}_{3}$ ] e a rocha é denominada de carbonatito alcalino, cujo único registro é no vulcão da Tanzânia.

Streckeisen (1979) também propõe designações das rochas em relação da porcentagem (cálcio e magnésio), sendo denominado de calcita carbonatito (90-100\% de $\mathrm{CaO})$, dolomita-calcita carbonatito (90-50\% de 
$\mathrm{CaO})$, calcita-dolomita carbonatito (50-90\% de $\mathrm{MgO})$ e dolomita carbonatito (90-100\% de $\mathrm{MgO}$ ).

No caso em que a identificação dos carbonatos não for possível, e a análise química de rocha total estiver disponível, os carbonatitos deverão ser classificados com base no diagrama CMF, atendendo a percentagem em peso, respectivamente de $\mathrm{CaO}, \mathrm{MgO}$ e $\left(\mathrm{FeO}+\mathrm{Fe}_{2} \mathrm{O}_{3}+\right.$ $\mathrm{MnO})$. Na utilização desta proposta deve-se atender duas situações: as rochas apresentando teor de $\mathrm{SiO}_{2}>20 \%$ são definidas como "sílico carbonatito" e para rochas com teor de $\mathrm{SiO}_{2}<$ $20 \%$, em situação de indefinição dos carbonatos teremos: os "calciocarbonatitos", quando houver mais de $80 \%$ de $\mathrm{CaO}$, os "magnesiocarbonatitos" quando o $\mathrm{MgO}>\mathrm{FeO}$ $+\mathrm{Fe}_{2} \mathrm{O}_{3}+\mathrm{MnO}$ e os "ferrocarbonatitos" quando o $\mathrm{FeO}+\mathrm{Fe}_{2} \mathrm{O}_{3}+\mathrm{MnO}:>\mathrm{MgO}$ (Woolley, 1982). Adiciona-se a esta classificação os "natrocarbonatitos" ricos em (sódio e potássio).

O magma carbonatítico individualizado, menos frequente, pode originar-se diretamente por fusão de uma fonte mantélica, caso em que geralmente ocorre como corpos isolados, sem relação óbvia com outros tipos de rochas alcalinas, sendo designado carbonatito primário (Gittins, 1989).

Os carbonatitos em associação com os complexos ultrabásicos-alcalinos correspondem a produtos de magmas mantélicos gerados e instalados durante os eventos de reativação tectono-magmática, que intrudem à crosta terrestre a partir de um mecanismo de plumas mantélicas responsáveis pela geração de magma em rifting intracontinental, concentrados em sistemas de falhas e lineamentos profundos existentes na crosta que funcionariam como condutos permitindo o emplacement dessas rochas. Frequentemente formam domos circulares-ovalados, circundados por uma auréola de metassomatismo (fenitos) e apresentam alto grau de intemperismo, devido à rápida dissolução de seus componentes (Barker, 1989).

A forma mais comum de ocorrência de carbonatitos são estruturas complexas multifásicas em associação com rochas silicáticas alcalinas, na forma de complexos plutônicos, plugs, cone sheets, diques, raros sills, tefra e derrames, sendo que o volume do magma carbonatítico é sempre subordinado ao alcalino
(Barker, 1989).

Os carbonatitos estão comumente associados com rochas alcalinas, em complexos de origem magmática. A designação "rocha alcalina”, em termos de composição química, inclui associações em complexos sílico-alcalino, o que torna possível a identificação de várias séries petrogenéticas ou associações variando de saturadas a subsaturadas, de sódicas a potássicas e de básicas até ácidas.

Na maioria dos complexos carbonatíticos, a presença de uma auréola de metassomatismo é comum, resultado da transformação da rocha encaixante sujeita à interação com fluidos residuais do processo de cristalização do carbonatito. As rochas metassomáticas são designadas fenitos e o processo de transformação de fenitização, termos que foram propostos por Brögger (1921).

Os produtos gerais da fenitização em rochas encaixantes silicatadas parecem corresponder a diminuição gradual ou perda total do quartzo e o aparecimento de associações potássico-sódicas como piroxênios (aegirina), anfibólios sódicos (arfvedsonita), nefelina, flogopita, feldspatos alcalinos e carbonatos. Podem ainda, ser ricos em sódio produzindo albita \pm anfibólio sódico \pm aegirina ou em potássio produzindo feldspato potássico.

A evolução desses complexos geralmente apresenta múltiplos estágios de intrusão e envolve processos petrogenéticos como cristalização fracionada e/ou imiscibilidade de líquidos, a partir de magmas primitivos alcalinos, sódicos ou potássicos. Os magmas primitivos sódicos, geralmente de composição nefelinítica dão origem às rochas silicáticas da série ijolítica (jacupiranguito-melteigitoijolito-urtito), enquanto magmas primitivos ultrapotássicos tendem a produzir sequências plutônicas bimodais, compostas por rochas ultramáficas (dunitos, clinopiroxenitos, bebedouritos) e por rochas félsicas (sienitos).

Segundo Gittins (1989) para a gênese dos magmas carbonatíticos considera-se essencialmente duas hipóteses concorrentes: a) fracionamento à baixa pressão na crosta de um magma parental derivado do manto (normalmente nefelinito carbonatado); e b) separação imiscível em níveis crustais pouco profundos do magma silicatado subsaturado depois de diferenciação prolongada. Uma terceira possiblidade considera 
um melt com origem no manto parcialmente carbonatado e metassomatizado que produzirá magmas carbonatitos primários e magmas silicatados separados.

Barker (1989) defende que o magma carbonatítico pode inicialmente ser baixo em álcalis, podendo fracionar e produzir líquido alcalino como produto final, ou gerar um líquido alcalino que uma vez contaminado pelas rochas hospedeiras originará líquidos calcíticos e dolomíticos.

Hall (1996) propõe três maneiras a partir das quais um magma carbonatítico pode se originar: (i) como produto inicial de fusão parcial de um manto portador de uma pequena proporção de carbonatos (carbonatitos primários); (ii) como produto final de diferenciação de um líquido silicático contendo carbonato dissolvido e; (iii) por imiscibilidade de líquidos em um sistema carbonatítico-silicático.

\section{CONTEXTO GEOLÓGICO}

As rochas paleoproterozoicas do Complexo Metacarbonatítico de Angico dos Dias estão situadas na divisa entre o município de Campo Alegre de Lourdes, extremo noroeste do Estado da Bahia, e o município de Caracol, extremo sul do Estado do Piauí, entre as coordenadas geográficas $09^{\circ} 15^{\prime} 00^{\prime \prime}$ e $09^{\circ} 36^{\prime} 00^{\prime \prime}$ de latitude sul e $43^{\circ} 02^{\prime} 00^{\prime \prime}$ e $43^{\circ} 31^{\prime} 00^{\prime \prime}$ de longitude oeste (Figura 1B).

Quanto aos aspectos geológicos estão inseridas no extremo norte do segmento geológico do Bloco Gavião (Barbosa \& Sabaté, 2004), intrusivas em uma associação de rochas gnáissicas e migmatíticas arqueanapaleoproterozoica do Complexo GnáissicoMigmatítico Sobradinho-Remanso. Localizam-se no contexto do limite norte do Cráton São Francisco (Almeida, 1977), com as faixas de dobramentos marginais Rio Preto e Riacho do Pontal (Alkmim et al., 1993) e, refletem um arcabouço tectônico superimposto Neoproterozoico (Leite, 1997) (Figura 1A).

Os trabalhos iniciais desta ocorrência de rochas metacarbonatíticas são da década de 1970 e as ocorrências minerais foram identificadas pela primeira vez na literatura geológica por Caldasso (1973). A partir desta ocorrência a Companhia Baiana de Pesquisa Mineral (CBPM) iniciou suas atividades geológicas regionais que se encontram descritas em Lima et al. (1977) e (Salviano et al. (1979).

Embora essas mineralizações já tivessem sido lavradas de modo rudimentar, foram consideradas antieconômicas pelas pesquisas até então realizadas. Os trabalhos geológicos do corpo carbonático intensificaram em 1984 pela CBMM, quando iniciou-se um programa de prospecção preliminar que resultou nos principais trabalhos da área produzidos por Silva et al. (1987, 1988 e 1997). A literatura geológica específica dos aspectos geológicos e mineralógicos destas rochas metacarbonatíticas são restritos a Lapin et al. (1999), Antonini et al. (2003) e, atualmente, Luciano (2016).

Silva et al. (1987) classificam as rochas como carbonatitos e/ou sovito e apresentando como mineralogia principal apatia, olivina serpentinizada, flogopita e magnetita, além da calcita. As rochas associadas ao complexo carbonático são constituídas por sienitos, que ocorrem lateralmente aos carbonatitos e subordinadamente por piroxenitos, álcali dioritos e lamprófiros, comumente gnaissificados e/ou milonitizados (Silva et al., 1988).

Lapin et al. (1999) destacam a morfologia linear dos seus corpos e a associação a cinturões móveis e a falhamentos profundos e, definem o Complexo Carbonatítico Angico dos Dias como o único do gênero conhecido até então no Brasil. Lateralmente, ao corpo carbonatítico, identificam uma zoneografia dos sienitos e sugerem que não se trata de uma sequência de rochas magmáticas intrusivas, mas sim, de fenitos reomórficos e metassomáticos, produzidos pela ação do magma carbonatítico sobre milonito-gnaisses.

Antonini et al. (2003) apresentam um enfoque isotópico para estas rochas e, apresentam pequenas adições e adaptações aos mapas dos autores já descritos.

Vários autores abordam especificamente a natureza da apatita nas frentes de lavra e, do aproveitamento e beneficiamento econômico do minério de fosfato de Angico dos Dias (Liberal \& Cassola, 1989); Kahn et al., 1990; Neumann \& Alcover, 1999 e Santos, 2001). 


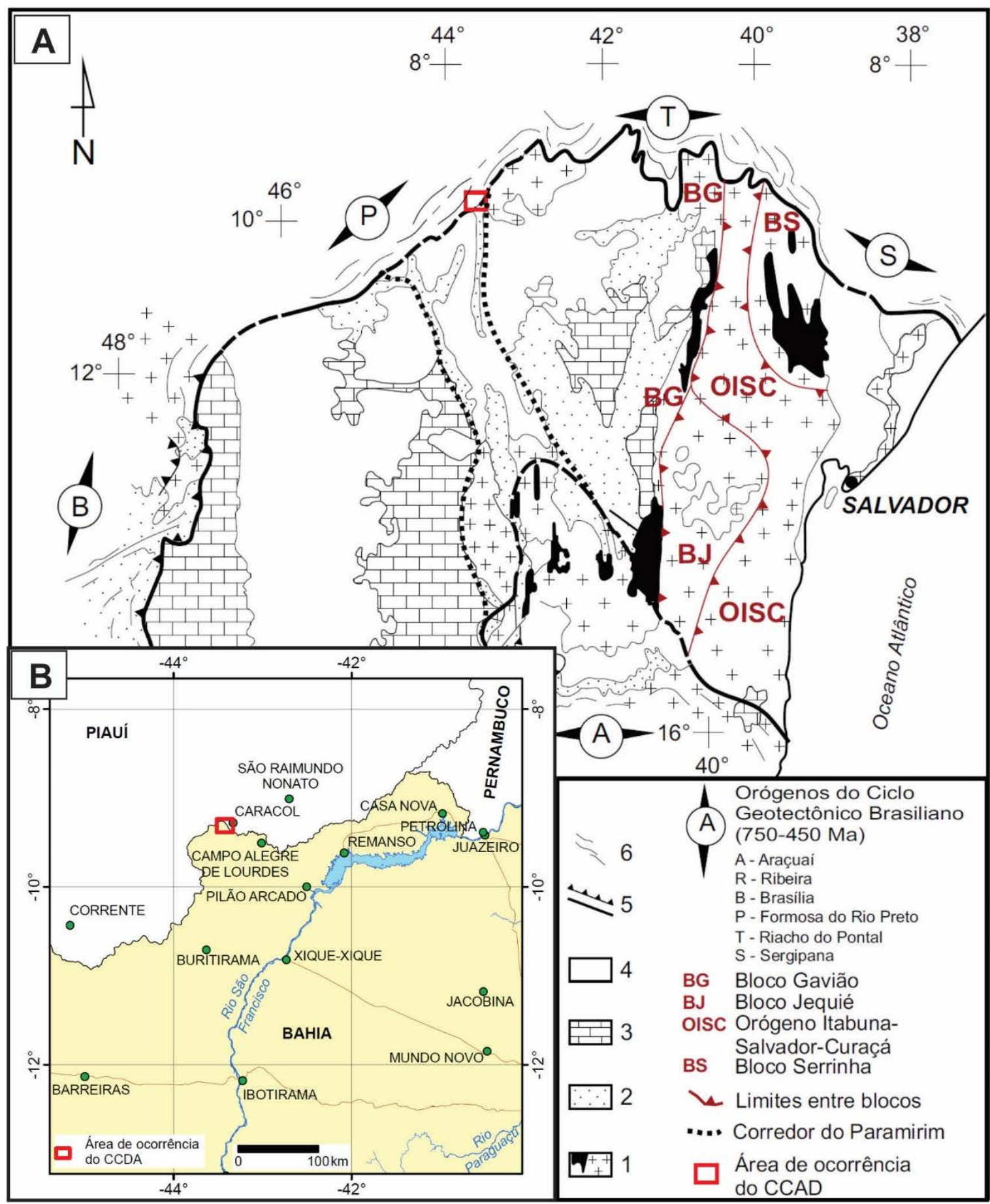

Figura 1 - A) Mapa esquemático apresentando os limites e as maiores unidades estruturais do Cráton São Francisco. B) Mapa de localização da área. Adaptado de Bizzi et al. (2003), Alkmim et al. (1993) e Leite (1997).

As atividades de mineração somente tiveram início em 2005, pela Empresa GALVANI Unidade de Mineração de Angico dos Dias, por meio de tecnologia de concentração a seco, superando desse modo o grande desafio do empreendimento, a falta hídrica do semiárido.

\section{GEOLOGIA DA ÁREA}

Os metacarbonatitos dispõem-se em dois conjuntos de corpos com os direitos minerários pertencentes à Mineração Galvani e a CBPM.

O mapa geológico regional da figura 2A, apresenta a localização das rochas metacarbonatíticas da região da fazenda Pimenteiras e da mina de fosfato, enquanto a figura $2 \mathrm{~B}$ apresenta o mapa geológico da mina de fosfato da Mineração Galvani e a figura 2C apresenta o mapa geológico dos corpos secundários de expressão areal mais restrita de rochas metacarbonatíticas, estando localizados ao norte da lavra, nas proximidades da Fazenda Pimenteira. 


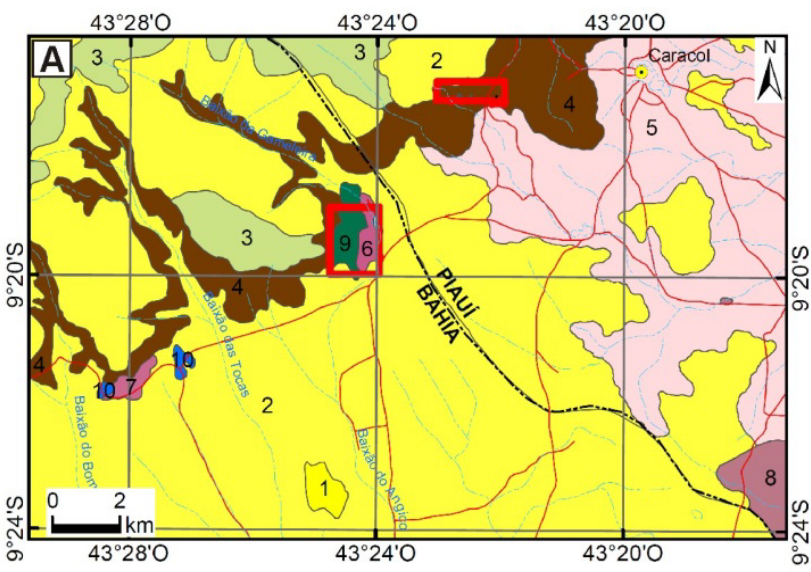

Legenda

Localidades $\quad$ Vias de Acesso
Área de ocorrência dos corpos de carbonatito.

Drenagem

Fomações Superficiais Cenozoicas - Plioceno-Pleistoceno (0,01 - 5Ma)

1 Areias eólicas.

2 Formações detríticas elúvio-coluviais.

Bacia do Parnaíba - Paleodevoniano-Neossiluriano (325 - 450Ma)

3 Grupo Canindé - Formação Pimenteiras: Folhelhos e siltitos.

Grupo Serra Grande - Formação Ipú: Arenitos conglomeráticos. Complexo Gnáissico-Migmatítico - Arqueano (>2,5Ga)

5 Ortognaisses a duas micas, de composição granítica, milonitizados.

6 Leucognaisses graniticos, milonitizados.

Rochas plutônicas atribuídas ao Paleo-Mesoproterozoico $(1,0$ - 2,5Ga) Suíte Alcalina Serra do Meio - Granitos alcalinos do tipo A (anorogênicos)

7 Fácies metaluminosa. 8 Fácies metaluminosa/peralcalina. Complexo Carbonatítico Angico dos Dias (2,0Ga)

9 Associação: carbonatito, sienitos, alcalidioritos e lamprófiros. Corpos Máfico-Ultramáficos Diversos

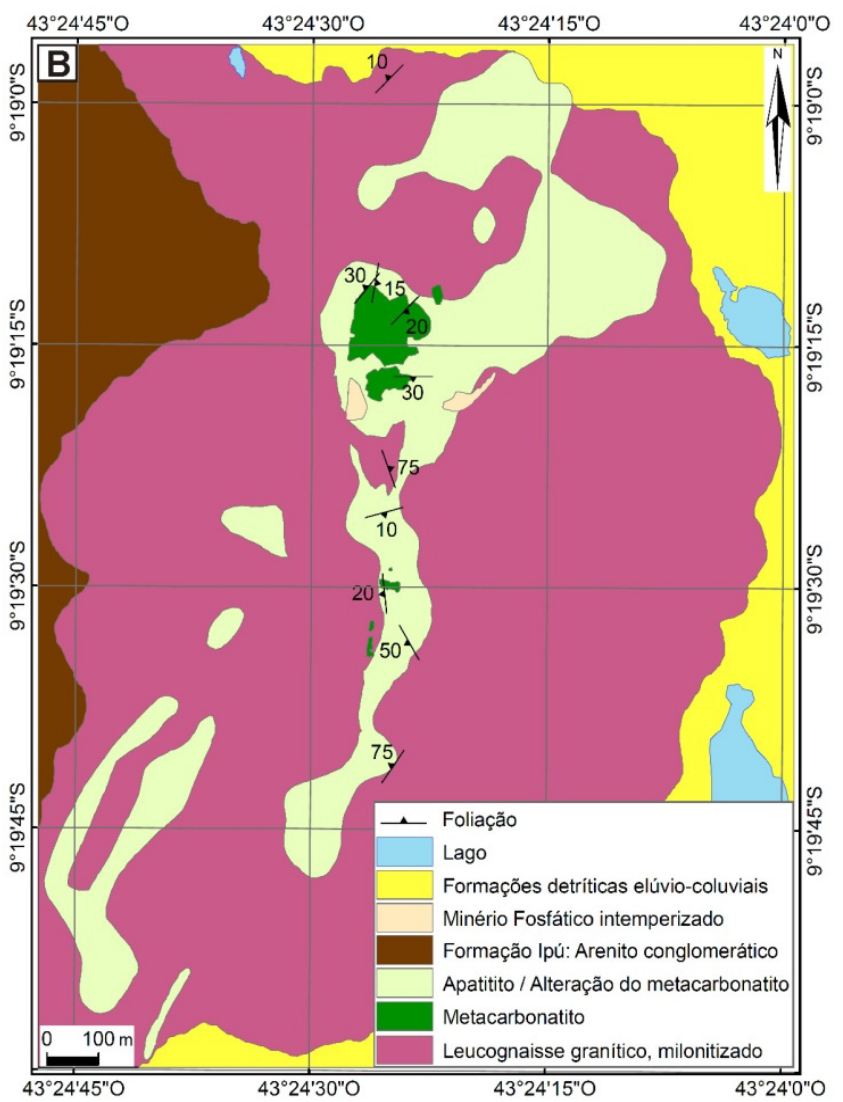

10 Metapiroxenitos, metagabros e clorita-actinolita xistos.

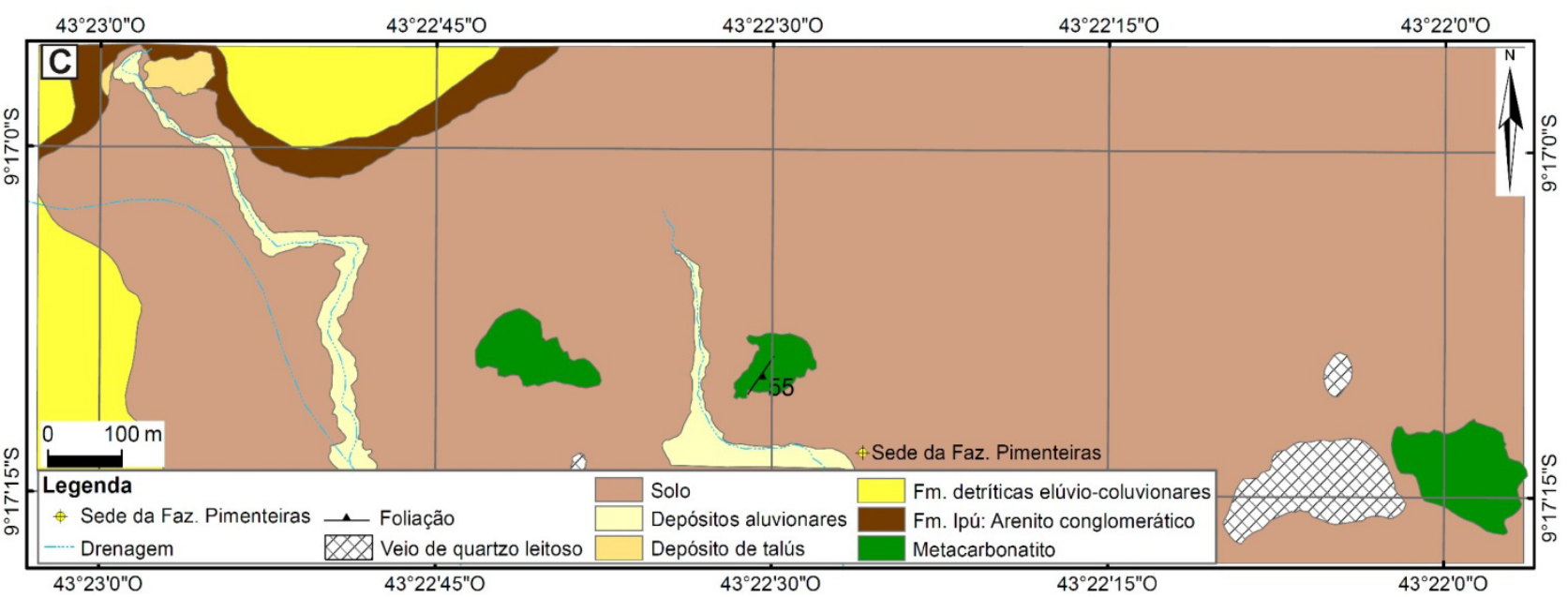

Figura 2 - A) Mapa geológico e de localização das rochas metacarbonatíticas da região da fazenda Pimenteiras e da mina de fosfato. B) Mapa geológico da mina de fosfato da Mineração Galvani. C) Mapa Geológico da região da fazenda Pimenteiras. Adaptado de Bizzi et al. (2003), Leite (1997) e Galvani (2013).

Segundo Luciano (2016) as rochas do Complexo Metacarbonatítico de Angico dos Dias constituem uma associação alcalinacarbonatítica intrusiva em ortognaisses graníticos, gnaisses migmatíticos de composição tonalítica-granodiorítica-trondhjemítica (TTG) e, gnaisses graníticos e anfibolíticos miloníticos.

São compostas predominantemente por metacarbonatitos (olivina-apatita metassovito, biotita-apatita metassovito e magnetita-olivina- apatita metassovito), expressivos metassienitos (meta-albititos, álcali feldspato metassienitos e quartzo metassienitos) e, secundariamente, metapiroxenitos, metadioritos, tremolititos e metalamprófiros.

O conjunto magmático apresenta localmente, transformações metassomáticas de fenitização e processo de silicificação, que se encontram parcialmente obliterada pelas feições metamórficas. Além disso, exibem manto intempérico, de espessura variável, associado às 
rochas carbonatíticas e que resultam no minério de fosfato residual, denominado de apatitito.

As rochas metassieníticas ocupam faixas alongadas e estreitas intrusivas e possuem uma morfologia tabular, por vezes lenticulares, orientados e controlados por falhas de direção NE-SW, que contornam os dois principais corpos de rochas metacarbonatíticas. O contato com o carbonatito é difuso e nele ocorrem com frequência zonas de biotitização decimétricas metassomáticas. Às vezes é possível individualizar um zoneamento gradual as diversas variedades de rochas metassieníticas.

Os metapiroxenitos são encontrados na forma de um corpo de tamanho expressivo e estão associados de forma concordante com os metassienitos e metacarbonatitos. Geralmente, ocorrem pequenos corpos associados a processos locais de diferenciação magmática, a partir de estruturas cumuláticas. A estas rochas encontra-se superimposto o metamorfismo de baixo grau Neoproterozoico que dá origem aos tremolititos.

As rochas metassienograníticas apresentamse foliadas e bandadas e estão associadas, de forma concordante, com os metassienitos e metacarbonatitos.

Os diques são sempre de dimensões reduzidas e os tipos litológicos mais comuns possuem composições lamprofíricas alcalinas variadas.

As rochas metacarbonáticas são classificadas principalmente como apatita sovito e/ou calciocarbonatito, granulação média a grossa constituídas necessariamente pela presença dominante de calcita e apatita, além de dolomita, olivina, flogopita, biotita, magnetita e serpentina.

\section{PETROGRAFIA DAS ROCHAS DO CMCAD}

As rochas do Complexo Metacarbonatíticos de Angico dos Dias (CMCAD) apresentam concentrações de apatita que são responsáveis pela formação de dois tipos de jazimentos fosfáticos: o primário e o secundário. O primário, representado predominantemente por apatita sovítos ou apatita calciocarbonatitos, foram originados por cristalização fracionada, principal mecanismo responsável pela evolução do magma, resultando em um acamamento cumulático definido por níveis mais enriquecidos em apatita, minerais ferromagnesiano e magnetita e possibilitando a geração das variedades de carbonatitos e as demais rochas ultrabásicas.

O secundário constitui nos depósitos residuais de espessura e teores irregulares instalado sobre as rochas metacarbonatíticas, originando o apatitito que ocorre associado com as carapaças ferruginosas e/ou silicificadas descontínuas. As análises petrográficas de várias fases minerais são dificultadas pela granulação micrométrica de alguns agregados, pelos efeitos de alteração metassomática e intempérica e pela natureza singular de algumas das fases minerais.

\section{Rochas Metacarbonatíticas}

Segundo Luciano (2016) os corpos de rochas metacarbonatíticas, apresentam litofácies distintas produzidas a partir de um mesmo magma carbonatítico diferenciado permite individualizar, a partir de contatos graduais, cinco fácies petrográficas principais: o metacarbonatito; olivina-apatita metacarbonatito; flogopita-apatita-olivina metacarbonatito; olivina-apatita-biotita/flogopita metacarbonatito e metacarbonatito silicificado e que encontramse identificada as mineralogias das fácies na tabela 1. As variedades são classificadas quanto ao seu padrão geoquímico em cálciocarbonatitos, ferrocarbonatitos e magnésiocarbonatitos (Luciano, 2016; Luciano \& Godoy 2017).

O Apatita Metacarbonatito (Ap. MC) é constituído principalmente por carbonato (>79\%), apresenta-se na cor cinza com porções verdes, com granulação fina e é encontrado na porção centro-sul da mina de fosfato da Galvani. Ocorre associado ao olivina apatita biotita/flogopita metacarbonatito.

Petrograficamente a rocha possui uma proporção de matriz relativamente elevada, de granulação fina e levemente orientada, composta por calcita $(<0,4 \mathrm{~mm})$ e minerais opacos (pirita e pirrotita $<0,15 \mathrm{~mm}$ ).

São identificadas texturas porfiroclástica de apatita (9\% a 15\%), com formas ovoides e fraturadas $(0,4$ e $5,0 \mathrm{~mm})$ e de calcita $(<6,5 \mathrm{~mm})$ imersos na matriz (Figura 3A).

A composição modal da matriz é de carbonato (79\% a $90 \%)$, pirrotita (1\%) e traços de pirita e de biotita. 
Tabela 1 - Porcentagens mineralógicas das rochas metacarbonatíticas.

\begin{tabular}{|c|c|c|c|c|c|c|c|c|c|c|}
\hline \multirow[t]{2}{*}{ Mineral (\%) } & \multicolumn{2}{|c|}{ Ap. MC } & \multicolumn{2}{|c|}{ Ol-Ap MC } & \multicolumn{2}{|c|}{ Phl-Ap-OI MC } & \multicolumn{2}{|c|}{ Ol-Ap-Bt/Phl MC } & \multicolumn{2}{|c|}{ MCS } \\
\hline & Mím. & Máx. & Mím. & Máx. & Mím. & Máx. & Mím. & Máx. & Mím. & Máx. \\
\hline Calcita & 84 & 90 & 61 & 75 & 32 & 48 & & 30 & & tr \\
\hline Apatita & 9 & 15 & 15 & 30 & 17 & 30 & 17 & 60 & & $43 \%$ \\
\hline Biotita-Flogopita & & 1 & & 10 & 2 & 20 & 20 & 65 & & $3 \%$ \\
\hline Olivina-Serpentina & & & & 10 & 20 & 27 & 0 & 18 & & $1 \%$ \\
\hline $\begin{array}{c}\text { Opacos-Pirrotita } \\
\text { Ilmenita-Perovskita }\end{array}$ & $\operatorname{tr}$ & 1 & 1 & 8 & $\operatorname{tr}$ & 4 & 10 & 40 & tr & $7 \%$ \\
\hline Quartzo & & & & & & & & 30 & 55 & 100 \\
\hline Anfibólio. & & & & 11 & & & & & & 2 \\
\hline Magnetita & & & & $\operatorname{tr}$ & & $\mathrm{tr}$ & & tr & & tr \\
\hline Epidoto & & & & & & & & & tr & 1 \\
\hline Clorita & & & & $\operatorname{tr}$ & & & & & & tr \\
\hline Piroxênio & & & & & & & & & & $\operatorname{tr}$ \\
\hline Perovskita & & & & & & & & & & $\operatorname{tr}$ \\
\hline Zircão & & & & & & & & & & tr \\
\hline Granada & & & & & & & & & & tr \\
\hline Limonita & & & & & & & & & & tr \\
\hline Titanita & & & & & & & & & & tr \\
\hline
\end{tabular}

O Olivina-Apatita Metacarbonatito (Ol-Ap $M C)$ possui elevado conteúdo de carbonato (61\% a $75 \%$ ) e ocorre comumente associado ao flogopita-apatita-olivina metacarbonatito.

Apresenta-se nas cores cinza esverdeado a amarela esverdeada a amarronzada, com granulação variando desde fina a muito grossa, com propriedades magnéticas e, bandamento composicional de espessura inferior a $15 \mathrm{~cm}$, marcado pela variação modal de biotita e minerais opacos, associado a uma foliação milonítica.

Petrograficamente a rocha apresenta textura porfiroclástica formada por uma matriz levemente orientada (Figuras 3B a 3F) composta por calcita $(<0,3 \mathrm{~mm})$, minerais opacos (magnetita e pirrotita: < 0,4mm), biotita/flogopita $(<0,6 \mathrm{~mm})$, mica branca e clorita, além de porfiroclastos ovoides e fraturados de apatita (0,2 e 6,0 $\mathrm{mm}$,), calcita $(4,8$ e $8,0 \mathrm{~mm}$ ), levemente alongada, fraturada e recristalizada, biotita/flogopita $(<1,6$ e $4,4 \mathrm{~mm})$, olivina serpentinizada $(<0,4$ e $9,0 \mathrm{~mm})$ e minerais opacos (1,2 e 1,3mm) associados a aos dois últimos minerais, bem como porfiroblastos de anfibólio (<0,4 e 2,4mm).

Os porfiroclastos de apatita exibem alguns raros subgrãos e fraturas preenchidas por mica branca, minerais opacos e carbonato. Podem apresentar raras inclusões de olivina serpentinizada, assim como porfiroclastos de olivina serpentinizada que apresentam raras inclusões de apatita. A olivina serpentinizada quando em contato com a matriz carbonática pode exibir feição de coroa de reação, onde constam anfibólio, serpentina e minerais opacos (predominantemente magnetita).

Alguns porfiroclastos de biotita/flogopita apresenta bordas descoloradas com baixa cor de interferência sugerindo atuação de processo de cloritização ou desferrificação. A pirrotita pode exibir exsoluções de pirita e calcopirita, assim como a magnetita pode exibir exsoluções de ilmenita. A magnetita revela indícios de oxidação intensa (pelo desenvolvimento de orlas de hematita) que, não raras vezes, são alteradas/substituídas por hidróxidos ou óxidos de ferro (goethita).

A composição modal para a matriz é de carbonato (30 a 75\%), minerais opacos (magnetita e pirrotita: (1 a 8\%) podendo ocorrer traços de clorita, biotita/flogopita e mica branca. Quanto aos porfiroclastos tem-se as seguintes proporções: apatita (15 a 30\%), carbonato (0 a 45\%), biotita e/ou flogopita (0 a $10 \%$ ) e minerais opacos (magnetita e pirrotita: (0 a 7\%). A olivina encontra-se transformada para serpentina (0 a 10\%) e para anfibólio (0 a $2 \%)$.

O Flogopita-Apatita-Olivina Metacarbonatito (Phl-Ap-Ol MC) possui baixo conteúdo de carbonato $(<32 \%)$ e é encontrado na porção norte da mina da Galvani associado ao olivinaapatita metacarbonatito. 

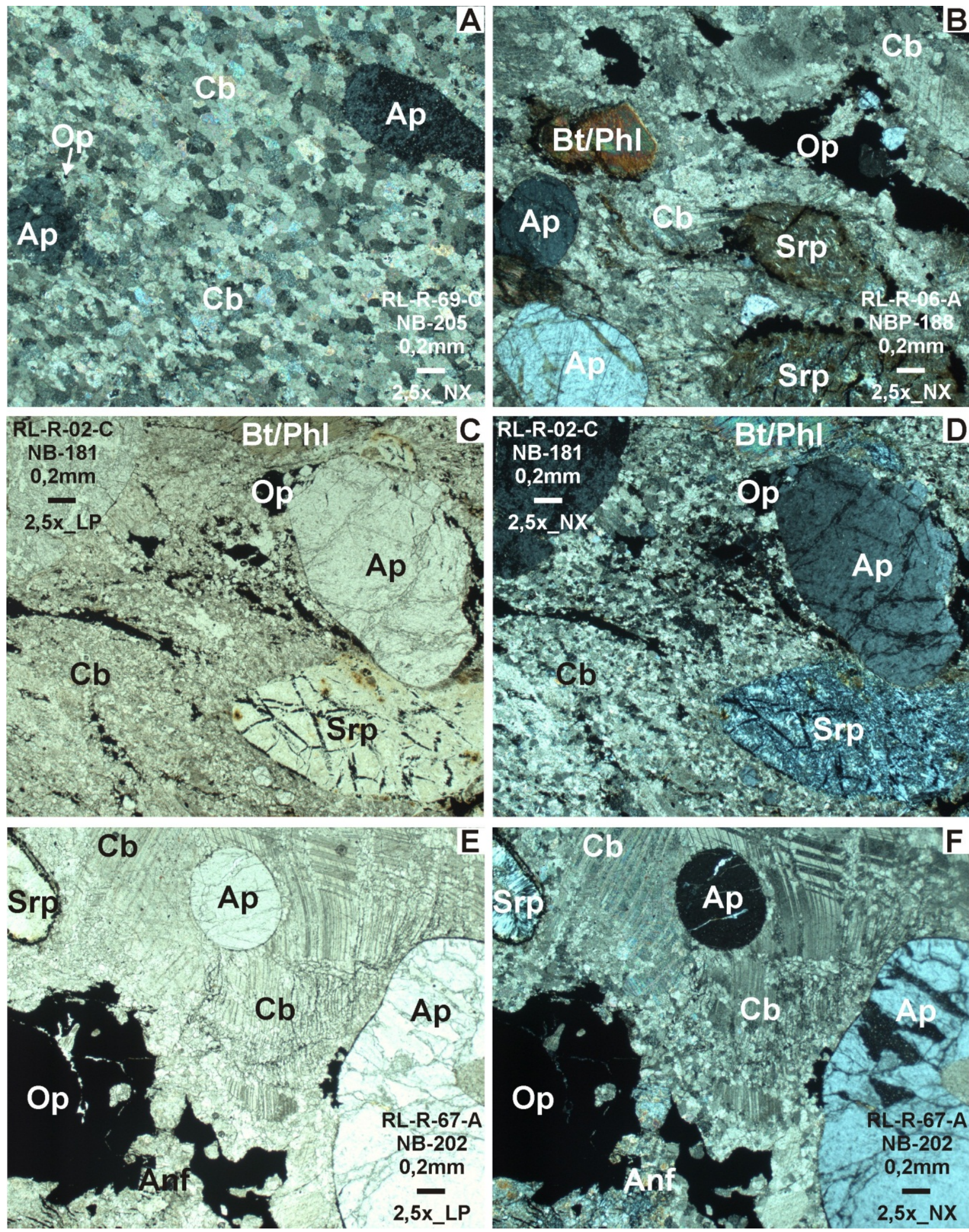

Figura 3 - Fotomicrografias: dos metacarbonatitos estudados. (A) Apatita Metacarbonatito com fenocristal de apatita (Ap) imerso em matriz constituída por carbonato (Cb) e minerais opacos (Op), luz polarizada (NX); (B) Olivina-Apatita Metacarbonatito com porfiroclastos de apatita (Ap), de pseudomorfos de olivina serpentinizada (Serp) e de minerais opacos (Op) imersos numa matriz composta por carbonato (Cb), biotita (Bt) e/ou flogopita (Phl) e minerais opacos (Op), luz polarizada (NX); (C e D) Olivina-Apatita Metacarbonatito com porfiroclastos de apatita (Ap), de pseudomorfos de olivina serpentinizada (Srp) e de minerais opacos (Op) imersos em matriz constituída por carbonato (Cb), biotita (Bt) e minerais opacos (Op), luz plana e polarizada, respectivamente (LP e NX); (E e F) Olivina-Apatita Metacarbonatito com porfiroclastos de calcita (Cb), de apatita (Ap), de pseudomorfos de olivina serpentinizada (Serp), de anfibólio (Anf) e de minerais opacos (Op) distribuídos numa matriz composta por carbonato (Cb) e minerais opacos, luz plana e polarizada, respectivamente (LP e NX). 
Apresenta-se nas cores verde, cinza e preta com porções esverdeadas a amarronzadas, com granulação média a grossa, destacando cristais dispersos de apatita e de magnetita numa matriz carbonática.

Petrograficamente a rocha apresenta-se com textura cumulática e porfirítica, onde se destacam megacristais ovalados de apatita (< $7,0 \mathrm{~mm}$ ), pseudomorfos de olivina serpentinizadas (arredondadas, alongadas e fraturadas), minerais opacos associados a palhetas dobradas de biotita/flogopita (< $4,0 \mathrm{~mm}$ ) e porfiroclastos de calcita em contato reto com a biotita/flogopita (Figuras 4A e 4B), imersos em uma matriz levemente orientada, composta por calcita $(<2,0 \mathrm{~mm})$ e minerais opacos (magnetita).

É comum a exsolução de ilmenita em porfiroclastos de magnetita (> 1,4mm). A serpentina está presente como concentrações de granulação entre 0,5 e $3,2 \mathrm{~mm}$ associada a minerais opacos no interior ou nas bordas externas de pseudomorfos de olivina, formando faixas que preenchem provavelmente antigas fraturas do mineral primário e na forma de palhetas dispersas na matriz. Os porfiroclastos de apatita exibem raros subgrãos e fraturas preenchidas por mica branca, minerais opacos e carbonato. A composição modal para a matriz é de calcita (32 a 48\%), de minerais opacos (magnetita: 0 a 3\%) e traços de mica branca. Além de porfiroclastos de olivina serpentinizada (20 a 27\%), de flogopita (2 a $20 \%$ ), de apatita (17 a 30\%) e de minerais opacos (magnetita $<1 \%$ ).

O Olivina-Apatita-Biotita/Flogopita Metacarbonatito (Ol-Ap-Bt/Phl MC) possui quartzo que substitui parcialmente o carbonato $(<30 \%)$, é encontrado na porção sul e central da mina da Galvani associada ao metacarbonatito silicificado, ao apatita metacarbonatito e ao gnaisse milonitizado. Apresenta-se nas cores branca, verde e marrom com porções verde, branca e amarela, com granulação variando entre muito fina a grossa, com cristais de biotita/flogopita em torno de $1,5 \mathrm{~cm}$ e com resquício de carbonato nas cavidades e poros. Observa-se bandamento composicional (Figuras 4C e 4D), cortado por foliação associada à zona de cisalhamento. Fraturas e veios milimétricos de calcita são observados. Petrograficamente apresenta-se com textura porfiroclástica milonítica e com bandamento composicional. Uma banda é formada por um mosaico contendo palhetas de biotita/flogopita ( $<2,0 \mathrm{~mm}$ ), porfiroclastos de biotita/flogopita microdobrados, estirados e fraturados, de apatita fraturada $(0,2$ a $8,0 \mathrm{~mm})$ e de pseudomorfos de olivina completamente serpentinizada ( $>8,0 \mathrm{~mm})$. A outra banda é composta por concentrados xenomórficos, que se dispõem numa matriz muito fina, representada por flogopita, quartzo e minerais opacos $(<1,2 \mathrm{~mm})$. Observam-se porfiroclastos de biotita/flogopita e de apatita, que exibem extinção ondulante com formação de alguns raros subgrãos e intenso fraturamento, com algumas fraturas preenchidas por sericita, minerais opacos e carbonato.

A composição modal para ambas as bandas é respectivamente de biotita/flogopita (31\% e $22 \%$ ), apatita (13\% e $4 \%)$, pseudomorfos de olivina serpentinizadas (4 e 14\%), de minerais opacos (2 e 10\%) e ocorrendo traços de sericita na primeira banda. No geral, a composição modal, varia entre biotita/flogopita (1 a 65\%), de apatita (4 a $40 \%$ ), de minerais opacos (2 a $40 \%$ ), quartzo (0 a 30\%) e pseudomorfos de olivina serpentinizadas (0 a 20\%).

O Metacarbonatito Silicificado (MCS) possui elevado conteúdo quartzo (55\% a $100 \%$ ), que substitui a calcita nas fases iniciais da deformação. É encontrado sotoposto ao olivina apatita-biotita-flogopita metacarbonatito na Mina Galvani e a NW e a SW da sede da Fazenda Pimenteiras, sob a forma de blocos e matacões e em situ, associado ao olivinaapatita-biotita/flogopita metacarbonatito. Apresenta-se nas cores branca, marrom, cinza e preta, com granulação muito fina a grossa, envolvendo cristais/cavidades arredondadas com tamanhos menores $1,5 \mathrm{~cm}$, com porções contendo carbonato, com veios com espessura de $1,0 \mathrm{~mm}$ de cor branca nas bordas e cor cinza escura no centro, com pequenos geodos/cavidades de dimensões inferiores $0,7 \mathrm{~cm}$ preenchidas por quartzo cristalino. Estas rochas apresentam-se com ou sem propriedades magnéticas (Figuras 4E e 4F).

Petrograficamente apresenta-se com textura porfiroclástica, granular, representada por uma matriz composta por quartzo, minerais opacos (magnetita, ilmenita e pirrotita, inferiores à 3,2mm), biotita/flogopita $(<2,0 \mathrm{~mm})$, calcita $(<$ 
0,25mm), ilmenita, goethita/limonita, piroxênio/clorita/epídoto, sericita, zircão, perovskita, contendo porfiroclastos de apatita
(0,55 e 10mm), titanita (traço), concentrações de biotita/flogopita, anfibólio alterado $(<$ $1,6 \mathrm{~mm})$ e serpentina.
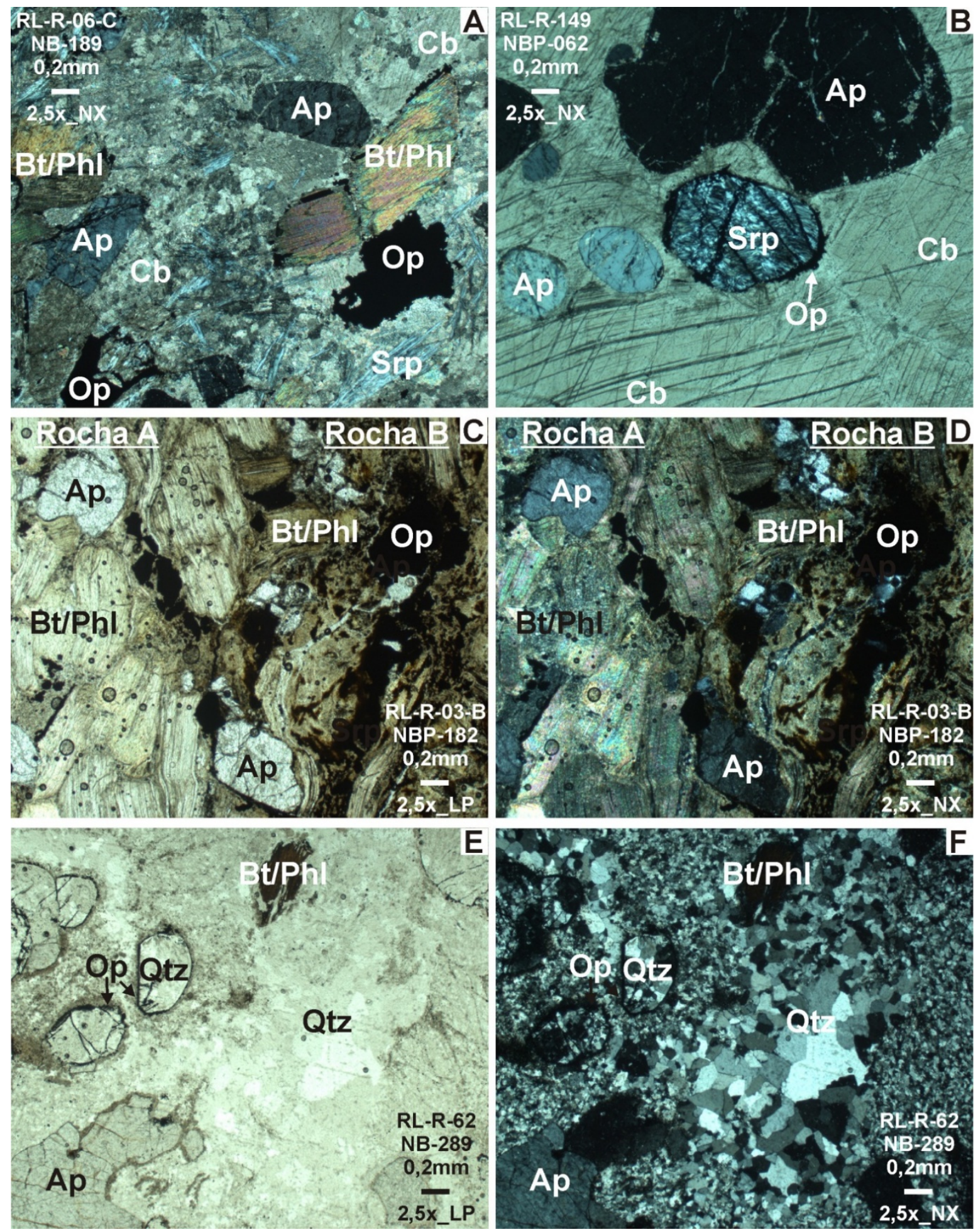

Figura 4 - Fotomicrografias de seções delgadas dos metacarbonatitos estudados: (A) Flogopita-Apatita-Olivina Metacarbonatito com uma matriz composta por carbonato (Cb), biotita (Bt) e/ou flogopita (Phl), minerais opacos (Op) e pórfiros de apatita (Ap), serpentina-olivina (Srp) e minerais opacos (Op), luz polarizada (NX); (B) Flogopita-ApatitaOlivina Metacarbonatito com porfiroclastos de apatita (Ap), de pseudomorfos de olivina serpentinizada (Serp) e de carbonato, luz polarizada (NX); (C e D) Olivina-Apatita-Biotita-Flogopita Metacarbonatito com bandamento composicional marcado pela concentração de minerais opacos e biotita (Bt) e/ou flogopita (Phl) na banda B; constituída por biotita (Bt) e/ou flogopita (Phl), apatita (Ap) e minerais opacos (Op), luz plana e polarizada, respectivamente (LP e NX); (E e F) Metacarbonatito Silicificado com uma matriz composta por quartzo (Qtz), minerais opacos (Op), biotita (Bt) e/ou flogopita (Phl) e porfiroclastos de apatita (Ap), luz plana e polarizada, respectivamente (LP e NX). 
O quartzo pode ocorrer em bolsões arredondados a alongados, com tamanhos entre 0,2 e $2,8 \mathrm{~mm}$, feições esqueletais de olivina serpentinizada ou faixa alongada e dobrada com até 1,6mm de espessura (antigas fraturas/veios), contendo cristais de tamanhos de 0,2 e $0,8 \mathrm{~mm}$. A apatita exibe feição que sugere um processo de dissolução nas bordas, com contração de mica branca.

Além disso, apresentam fraturas preenchidas por quartzo, minerais opacos e goethita. A magnetita e a ilmenita correspondem geralmente aos maiores grãos de minerais opacos, contudo grânulos finíssimos de pirrotita e magnetita podem compor a matriz. A ilmenita ocasionalmente encontra-se oxidada, transformando-se para gohetita e limonita. Nas bordas dos maiores cristais de biotita/flogopita é possível verificar variação de coloração, sugerindo processo inicial de cloritização.

A composição modal para a matriz é de quartzo (55 a 90\%), de minerais opacos (pirrotita e magnetita: < 5\%), de biotita/flogopita $(<1 \%)$, epidoto $(<1 \%)$, além de traços de goethita, limonita, sericita, zircão, clorita, carbonato, piroxênio e perovskita. Quanto aos porfiroclastos são observadas: apatita (15 a 43\%), minerais opacos (magnetita e ilmenita: (< 7\%), flogopita (<3\%), anfibólio $(<2 \%)$, serpentina $(<1 \%)$ e titanita (traço).

\section{Rochas Associadas ao CMCAD}

As demais rochas identificadas em associação aos carbonatitos neste trabalho são metassienito, metassienogranito, tremolitito, biotita xisto e fenitos. Essas rochas encontramse milonitizadas e hidrotermalizadas, não sendo possível individualiza-las das rochas carbonatíticas em função da pequena abrangência e escala trabalhada.

O metassienito é encontrado na porção central da mina da Galvani e ocorre associado olivina-apatita-biotita/flogopita metacarbonatito e ao biotita xisto. Apresenta-se nas cores branca a amarelo claro com porções pretas a verdes, com granulação fina a grossa. Petrograficamente é formado por um mosaico de megacristais bimodais de feldspato pertítico de tamanhos de inferior $2,0 \mathrm{~mm}$ e superior $12,0 \mathrm{~mm}$ e plagioclásio. São comuns cristais intersticiais de quartzo $(<2,4 \mathrm{~mm})$, minerais opacos inferior a $0,5 \mathrm{~mm}$, biotita eventualmente intersticial inferior a 2,8mm (Figuras 5A e 5B), clinozoisita $(0,05$ e $0,1 \mathrm{~mm})$, titanita inferior a $0,4 \mathrm{mme}$ zircão $(0,4 \mathrm{~mm})$. A composição modal é 95 a 81\% de feldspato alcalino, menos de $19 \%$ plagioclásio, 4 a $6 \%$ de quartzo, menos de $3 \%$ de minerais opaco, menos de $1 \%$ de biotita e traços de titanita e de minerais secundários (sericita, epídoto e gohetita).

O metassienogranito milonitizado é encontrado na porção central da mina da Galvani. Milonitizado, apresenta-se na cor marrom esverdeada, com granulação entre muito fina e fina. Petrograficamente apresentase com textura granolepdoblástica, milonítica. É formado por porfiroclastos de plagioclásio (< $2,0 \mathrm{~mm}$ ), cristais de epidoto, de quartzo, de minerais opacos, de muscovita/sericita (< 2,0mm) e de leucoxênio (Figuras 5C e 5D). Os porfiroclastos de plagioclásio estão estirados, resultando em feições sigmoidais, dobrados e intensamente alterados pelos processos de sericitização e saussuritização.

O tremolititos apresenta tremolita (90\%) e minerais opacos (10\%) e é encontrado sob a forma de pequenos blocos rolados na região norte da sede da Fazenda Pimenteiras. Petrograficamente exibe textura nematoblástica, onde se observam cristais prismáticos e aciculares de tremolita, por vezes impregnados com óxido de ferro, resultantes de alteração de provável magnetita (Figuras 5E e 5F).

\section{Considerações Petrográficas}

As variedades de rochas carbonatíticas do CMCAD, geralmente são dominadas pelas grandes variações composicionais de cristais cumuláticos desenvolvidos nas fases iniciais do processo de cristalização fracionada (segregação gravítica), imersos numa matriz de composição carbonática. As variações composicionais e texturais definidas a partir dos cristais de olivina serpentinizada, apatita, flogopita e minerais opacos imprimem a constituição das variedades litológicas dos carbonatitos, além de ocorrerem localmente também disseminações, segregações e bolsões de minerais principalmente de magnetita. Em função dos vários fatores superimpostos, tem-se uma natureza composicional, textural e estrutural adicional evidenciando relativa heterogeneidade, devido ao grau de alterações presentes no material rochoso. 

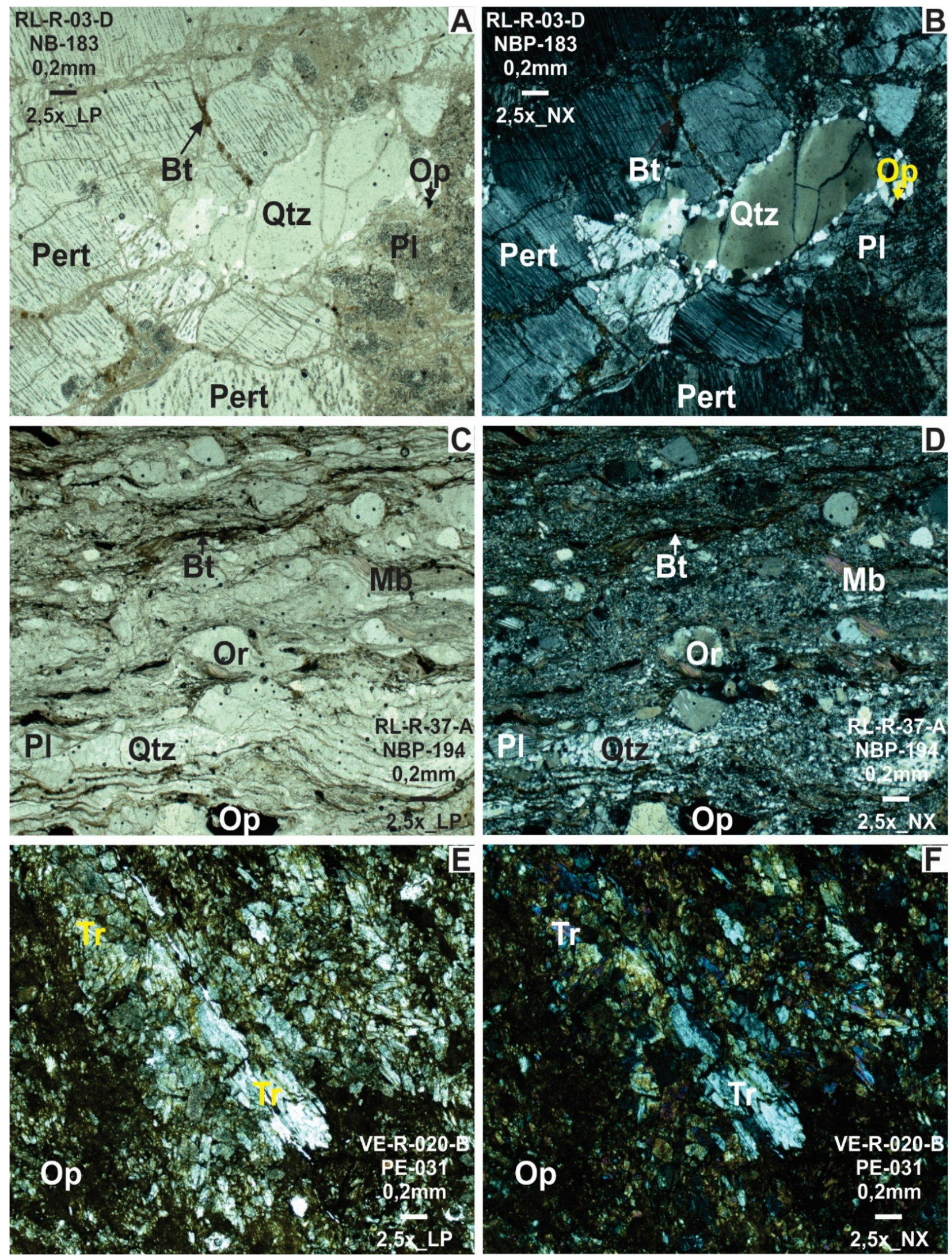

Figura 5 - Fotomicrografias: A e B) Metassienito, C a D) Metassienogranito e E e F) Tremolitito: (A e B) Metassienito com textura granoblástica, porfiroclástica, formada por um mosaico de megacristais de pertita (Pert), plagioclásio (Pl), quartzo (Qtz) e biotita (Bt), luz plana e polarizada, respectivamente (LP e NX); (C e D) Metassienogranito com textura granolepdoblástica, porfiroclástica, formada por uma matriz de granulação fina composta por quartzo, epidoto (Ep), sericita/muscovita (Ms), leucoxênio (Lcx) e minerais opacos, luz plana e polarizada, respectivamente (LP e NX); (E e F) Tremolitito constituído por cristais de tremolita (Tr) alterados e minerais opacos (Op), luz plana e polarizada, respectivamente (LP e NX). 
Os calciocarbonatitos são de composição dominantemente calcítica, de granulação fina a grossa. As fases fosfatadas são representadas por grãos de apatita disseminados na matriz.

Ocorrem disseminações na matriz de cristais de piroxênios, parcialmente ou totalmente substituído por agregados com hábitos aciculares de anfibólios retrometamórficos.

As magnetitas, ao contrário do que acontece nos ferrocarbonatitos, não desenvolvem disseminações relevantes, mas apresentam-se alteradas para hidróxidos e óxidos de $\mathrm{Fe}$ (goethita), que ocorrem associados a estágios tardios, principalmente ao longo de pequenos veios e fraturas.

Para os ferrocarbonatitos a matriz é de granulação fina a média e é constituída essencialmente por agregados finos de carbonato, essencialmente calcita, por vezes dolomita.

Destaca-se a presença variável e abundante de magnetita magmática, muitas vezes constituindo bolsões de granulação grossa, que por processos metassomáticos, intensificados pela meteorização química, preservam efeitos de oxidação intensa, geralmente materializada pelo desenvolvimento de orlas hematíticas, muitas vezes substituídas por hidróxidos e óxidos de ferro e manganês, os quais ocorrem associados a fraturas.

Em função dos fatores superimpostos temos a natureza composicional, textural e estrutural relativamente heterogênea. Os fatores superimpostos devem-se à sobreposição de transformações por processos tardi-magmáticos e magmático-hidrotermais/metassomáticos, associados às etapas finais de consolidação e arrefecimento do corpo ígneo, em boa parte síncronas aos processos de fenitização, envolvendo: disseminações heterogêneas, bolsões, veios e substituições.

Os processos generalizados metamórficos são dominantemente de hidratação mineral em fácies xisto verde médio, originam uma série de minerais superimpostos metamórficos, que apresentam intensidades distintas de deformações tectônicas, responsáveis pelas feições foliadas (regionais e/ou miloníticas), pela recristalização dos carbonatos, pela geração de serpentina, anfibólio (actinolita/tremolita) e minerais opacos secundários gerados a partir da desestabilização de olivinas e pelo processo de cloritização ou desferrificação da biotita/flogopita.

Processos metassomáticos, resultaram ainda na cristalização de biotita/flogopita na matriz carbonática e na substituição do carbonato pela sílica (processo de silicificação), geralmente associados a processos deformacionais dúctilrúpteis.

Depósitos formados por enriquecimento residual a partir de processos de meteorização química incidem sobre as rochas do complexo carbonatítico e minerais são concentrados em horizontes do perfil de meteorização, resultando o minério secundário acumulativo (apatititos).

Os processos tardios, posteriormente intensificados pela meteorização química, são cruciais ao desenvolvimento de associações mineralógicas que, com frequência, constituem disseminações na matriz tardia e preenchimentos de redes de veios, filonetes e venulações.

Os fenitos, associados às fases silicatadas com associações potássico-sódicas são observáveis nos metassienitos. Estas associações caracterizam-se pela presença de agregados de feldspatos (microclínio e albita) que constituem a matriz.

Localmente, ocorre venulações tardias apresentando agregados de hidróxidos e óxidos de ferro (hematita + goethita), traduzindo meteorização química relativamente intensa na área. A esta fase silicatada destaca-se a presença de fases acessórias como apatita, óxidos de ferro e de titânio.

Os fenitos, associados às fases carbonatadas são abundantes e apresentam a matriz resultante essencialmente calcítica ou quartzosa, resultantes de processos de carbonatação.

As rochas encontram-se deformadas e apresentam metamorfizadas em fácies xisto verde médio responsável pela hidratação e transformações metamórficas dos minerais, a exemplo, a desestabilização de piroxênio e consequente geração de tremolitas, além de processos de sericitização, saussuritização e epidotização.

\section{CONCLUSÕES}

O Complexo Metacarbonatítico Angico dos Dias é constituído dominantemente por corpos 
de metacarbonatitos, metassienitos variados e metapiroxenitos, além de raros metassienogranitos, tremolititos e diques diversos de metalamprófiros, intrusivos em metatonalitos, metaleucogranitos e granulitos.

As rochas são classificadas dominantemente como calciocarbonatito e são constituídas principalmente por calcita e apatita e, subordinado dolomita, olivina, flogopita e magnetita. A variação no conteúdo de apatita, minerais ferro-magnesianos e magnetita, constituem um acamamento cumulático, que é o principal mecanismo responsável pela evolução do magma, possibilitando individualizar cinco litotipos petrográficos: apatita metacarbonatito; olivina-apatita metacarbonatito; flogopita-apatita-olivina metacarbonatito; olivina-apatita-biotita/flogopita metacarbonatito e metacarbonatito silicificado.

O conjunto magmático apresenta localmente transformações metassomáticas de fenitização, sendo o processo mais abrangente constitui o de silicificação. Um espesso manto de intemperismo, proveniente da alteração dos metacarbonatitos primários, concentra-se sobre estes, constituindo um importante depósito de fosfato residual, denominado de apatitito.

$\mathrm{O}$ conjunto magmático encontra-se metamorfizado no Paleoproterozoico em fácies anfibolito alto com superposição de paragêneses em fácies xisto-verde média de idade neoproterozóica.

Ocorrem frequentes transformações metamórficas caracterizadas por processos de sericitização/ muscovitização, saussuritização, cloritização e epidotização.

A evolução das rochas metacarbonatíticas paleoproterozóicas encontram-se inicialmente associadas à formação de plumas mantélicas e o domeamento crustal, que por mecanismos distensivos resulta no rifteamento da crosta de composição tonalíticas-granodioríticas-trondhjemítica de idade arqueana-paleoproterozoica do Complexo Sobradinho-Remanso.

A partir dos efeitos descompressionais há geração e emplacement dos carbonatitos em grandes falhamentos profundos. Posteriormente, uma tectônica colisional paleoproterozoica em fácies anfibolito alto afeta todo o conjunto de rochas da área.

A tectônica colisional (tangencial e transcorrente) Neoproterozoica superimposta foi responsável pelo formato lenticular dos corpos do minério e as associações minerais antigas são superpostas por paragêneses metamórficas em fácies xisto verde médio.

\section{AGRADECIMENTOS}

Os autores agradecem ao apoio da Companhia Baiana de Pesquisa Mineral (CBPM) e a Mineração Galvani

\section{REFERÊNCIAS}

ALKMIM, F. F.; BRITO NEVES, B. B. DE B.; ALVES, J. A. C. Arcabouço tectônico do Cráton São Francisco: uma revisão. In: SIMPÓSIO SOBRE O CRÁTON SÃO FRANCISCO, 2. 1993, Salvador. Anais...Salvador: SBG/SGM, v. 1, p. 45-62.

ALMEIDA, F. F. M. DE. O Cráton São Francisco. Revista Brasileira de Geociências, v. 7, n. 4, p. 349-367, 1977.

ANTONINI, P.; COMIN-CHIARAMONTI, P.; GOMES, C. B.; CENSI, P.; RIFFEL, B .F.; YAMAMOTO, E. The Early Proterozoic carbonatite complex of Angico dos Dias, Bahia State, Brazil: geochemical and Sr-Nd isotopic evidence for an enriched mantle origin. Mineralogical Magazine, v. 67, n. 5, p. 1039-1057, 2003.

BARBOSA, J. S. F. \& SABATÉ, P. Archean and Paleoproterozoic crust of the São Francisco Craton, Bahia, Brazil: geodynamic features. Precambrian Research, v. 133, p. 1-27, 2004.

BARKER, D. S. Field relations of carbonatites. In: Carbonatites, Genesis and Evolution (Bell, K. Ed.), Unwin Hyman Ltd. London: p. 38-63, 1989.

BIZZI, L. A.; SCHOBBENHAUS, C.; VIDOTTI, R. M.; GONÇALVES, J. H. Geologia, Tectônica e Recursos Minerais do Brasil: Brasília: CPRM - Serviço Geológico do Brasil, 692 p., 2003.

BOSE, P. N. Geology of Lower Narbada Valley between Nimáwar and Káwant. Memoirs of the Geological Survey of
India, v. 21, p. 1-72, 1884.

BROD, J. A. Épocas e Fases Metalogenéticas das Província Carbonatíticas do Brasil. Apresentação PowerPoint. Universidade Federal de Goiás - Instituto de Estudos SócioAmbientais. 40p., 2014.

BRÖGGER, W. C. Die Eruptivgesteine des Kristianniagebietes. IV. Das Fengebiet in Telemarken, Norwegen. Norske Videns. Skrift. Mat. Naturv. Klasse, n. 9, 1921.

CALDASSO, L. S. Projeto Sudeste do Piauí I: relatório final integrado. Recife: CPRM, 1973.

COMIN-CHIARAMONTI, P. \& GOMES, C. B. Mesozoic to Cenozoic Alkaline Magmatism in the Brazilian Platform. Editora da Universidade São Paulo, 750 p., 2005.

GALVANI. Mapa Geológico/Topográfico-localização de furos de sonda e cava, 1: 5.000, 2013.

GITTINS, J. The origin and evolution of carbonatite magmas. In: Carbonatites, Genesis and Evolution (Bell, K. ed.), Unwin Hyman, London, p. 580-599, 1989.

HALL, A. Igneous Petrology. Prentice Hall, p. 417, 1996. HEINRICH, E. W. The Geology of Carbonatites. Rand M.cNally and Comp., Chicago, 609 p., 1966.

HÖGBOM, A. G. Uber das Nephelinsyenitgebiet auf der Insel Alnö. Förh. Geol. Forën, v. 17, p. 100-160, 1895.

KAHN, H.; CASSOLA, M. S.; OBA, C. A. I.; LIBERAL, G. S. E.; RIFFEL, B. F. Caracterização tecnológica do minério 
residual de fosfato de Angico dos Dias, BA. In: ENCONTRO NACIONAL DE TRATAMENTO DE MINÉRIOS E HIDROMETALURGIA, 14, 1990, Salvador. Anais...Salvador. ABM: v.1, p. 196-211.

LAPIN, A. V.; RIWANUCHI, W.; PLOSHKO, V. V. Carbonatitos lineares de cinturões móveis: uma síntese. Revista Brasileira de Geociências, v. 29, p. 483-490, 1999.

LEITE, C. M. M. Campo Alegre de Lourdes, folhas SC. 23X-D-IV. Peixe, SC. 23-X-D-I: Estado da Bahia. Brasília: CPRM (Programa Levantamentos Geológicos Básicos do Brasil), 158, p. 1997.

LIBERAL, G. S. \& CASSOLA, H. L. O depósito de fosfato Angico dos Dias, Ba; geologia, beneficiamento e aproveitamento econômico. In: $3^{\circ}$ CONGRESSO BRASILEIRO DE MINERAÇÃO. 1989, São Paulo. IBM. Coletânea de Trabalhos... São Paulo, v. 2. p. 266-287.

LIMA, R. F. F.; SOARES, J. V.; SANTOS, L. M. B.; LADO, S. E. Projeto Fe-Ti de Campo Alegre de Lourdes - Fase I. Projetos Técnicos da Companhia Baiana de Pesquisa Mineral. 1977.

LUCIANO, R. L. Petrografia e geoquímica das rochas metacarbonatíticas do Complexo Angico dos Dias, divisa Bahia/Piaú, Brasil. Rio Claro, 2016. 273p. Tese (Doutorado), Instituto de Geociências e Ciências Exatas Universidade Estadual Paulista.

LUCIANO, R. J. \& GODOY' M. G. Geologia do Complexo Metacarbonatítico de Angico dos Dias, divisa Bahia/Piauí, Brasil. São Paulo, UNESP, Geociências, v. 36, n. 2, p. 301 314, 2017.

MARIANO, A. N. Analytival report on rocks from Angico dos Dias. Bahia, CBMM, 1987.

NEUMANN, R. \& ALCOVER, A. N. Caracterização mineralógica e tecnológica do minério fosfórico de Angico dos Dias/Caracol (BA/PI). Relatório técnico de Projeto PADCT (RT-09/99), 1999.

PECORA, W. T. Carbonatites, a review. Geological Society of America Bulletin, v. 67, p. 1537-1556, 1956.

SALVIANO, A.; SAMPAIO, D. R.; AZEVEDO, H. C. A.; OLIVEIRA, M. T. M. Projeto Fe-Ti de Campo Alegre de Lourdes-Fase II. Projeto Técnico. CBPM, 1979.

SANTOS, C. N. Micromorfologia, geoquímica e aspectos tecnológicos da apatita da associação alcalinometacarbonatítica pré-cambriana de Angico dos Dias, BA. São Paulo, 2001. 131p. Dissertação (Mestrado), Universidade de São Paulo, 131p., 2001.
SILVA, A. B.; LIBERAL G. S.; ISSA FILHO, A.; RODRIGUES, C. S.; RIFFEL B. F. Depósito de fosfato em carbonatito pré-cambriano, Angico dos Dias-Ba. Sociedade Brasileira de Geologia, Núcleo da Bahia, Salvador. 15p., 1987.

SILVA, A. B.; LIBERAL G. S.; GROSSI SAD, J. H.; ISSA FILHO, A.; RODRIGUES, C. S.; RIFFEL B. F. Geologia e petrologia do Complexo Angico dos Dias (Bahia, Brasil), uma associação metacarbonatíticas pré-cambriana. Geochimica Brasiliensis, v. 2, n. 1, p. 81-108, 1988.

SILVA, A. B.; LIBERAL, G. S.; RIFFEL, B. F.; ISSA FILHO, A. Depósito de fosfato de Angico dos Dias, Campo Alegre de Lourdes, Bahia. Principais Depósitos Minerais do Brasil, DNPM, p. 123-130, 1997.

STRECKEISEN, A. L. Classification and nomenclature of volcanic rocks, lamprophyres, carbonatites, and melilitic rocks: Recommendations and suggestions of the IUGS Subcommission on the Systematics of Igneous Rocks. Chainnan, IUGS Subcommission Mineralogishes Institut, Sahlistrasse, 6. Geology, v. 7, p. 331-335, 1979.

STUTZER, O. Eruptive Kalksteine. Wochenschrift, neue Folge, v. 25, p. 392-393. 1907.

WOOLLEY, A. R. A discussion of carbonatite evolution and nomenclature, and the generation of sodic and potassic fenites. Mineralogical Magazine, v. 46, p. 13-17, 1982.

WOOLLEY, A. R. Alkaline rocks and carbonatites of world, Part 3; Africa. London: Geological Society of London, 372p. 2001.

WOOLLEY, A. R. \& KEMPE, D. R. C. Carbonatites: Nomenclature, average chemical composition and element distribution. In: Carbonatites: Genesis and Evolution. Bell, K. (ed) Unwin Hyman, London, p 1-14, 1989.

WOOLLEY, A. R. \& KJARSGAARD, B. A. Paragenetic types of carbonatite as indicated by the diversity and relative abundances of associated silicate rocks: evidence from a global database. Canadian Mineralogist, n. 46, p. 741-752, 2008. 